\title{
Diet of Crossodactylus timbuhy (Anura: Hylodidae) in the Reserva Biológica Augusto Ruschi, state of Espírito Santo, Brazil
}

\author{
Elaine Costa Campinhos $^{1}$, Rodrigo Barbosa Ferreira ${ }^{2}{ }^{\mathbb{D}}$, Marcio Marques Mageski $^{1}$ \& Ana Carolina \\ Srbek-Araujo ${ }^{1,3,4 *(1)}$ \\ ${ }^{1}$ Universidade Vila Velha, Programa de Pós-graduação em Ecologia de Ecossistemas, Vila Velha, ES, Brasil. \\ ${ }^{2}$ Instituto Marcos Daniel, Projeto Bromeligenous, Vitória, ES, Brasil. \\ ${ }^{3}$ Universidade Vila Velha, Programa de Pós-graduação em Ciência Animal, Vila Velha, ES, Brasil. \\ ${ }^{4}$ Instituto SerraDiCal de Pesquisa e Conservação, Belo Horizonte, MG, Brasil. \\ *Corresponding author: Ana Carolina Srbek-Araujo, e-mail: srbekaraujo@hotmail.com
}

CAMPINHOS, E.C., FERREIRA, R.B., MAGESKI, M.M., SRBEK-ARAUJO, A.C. Diet of Crossodactylus timbuhy (Anura: Hylodidae) in the Reserva Biológica Augusto Ruschi, state of Espírito Santo, Brazil. Biota Neotropica 20(4): e20190943. https://doi.org/10.1590/1676-0611-BN-2019-0943

\begin{abstract}
Anurans are predator and prey, playing an important role in ecosystem functioning. The diet composition is closely related to feeding strategy, and the information about prey items is useful to understand intra and interspecific interactions in trophic webs. Here we determined diet composition, feeding strategy, and relation between prey ingestion and body measures of Crossodactylus timbuhy, a recently described anuran species. We found 466 prey items from 20 prey categories in the stomach of 66 specimens ( 15 males and 51 females) of C. timbuhy. The diet consists mostly of Formicidae and Coleoptera, the items with the highest number, frequency of occurrence and prey importance. The diet composition was relatively similar to other species of Crossodactylus. Prey volume was positively related to frog size and weight, suggesting frogs may feed upon any prey they can swallow. Diet showed some variation between sexes. Despite females were larger and heavier than males, females had higher consumption of smaller prey, and ingested a larger number of prey categories. We suggest C. timbuhy has an invertebrate-opportunistic feeding habit. It is likely C. timbuhy uses a combination of 'sit-and-wait' and 'active search' strategies due to high consumption of both highly mobile and sedentary prey.
\end{abstract}

Keywords: Amphibia; Atlantic Forest; dietary preference; feeding ecology; predation.

\section{Dieta de Crossodactylus timbuhy (Anura: Hylodidae) na Reserva Biológica Augusto Ruschi, Espírito Santo, Brasil}

Resumo: Os anuros são predadores e presas, desempenhando um importante papel no funcionamento dos ecossistemas. A composição da dieta está intimamente relacionada à estratégia de forrageamento das espécies e as informações sobre os itens consumidos são úteis para compreensão das interações intra e interespecíficas nas redes tróficas. O presente estudo objetivou determinar a composição da dieta, a estratégia de forrageamento e a relação entre a ingestão de presas e as medidas corporais de Crossodactylus timbuhy, uma espécie de anuro descrita recentemente. Foi analisado o conteúdo estomacal de 66 espécimes (15 machos e 51 fêmeas) de C. timbuhy e registrados 466 itens alimentares, distribuídos em 20 categorias de presas. A dieta consistiu principalmente de Formicidae e Coleoptera, as quais apresentaram maior número de itens consumidos, maior frequência de ocorrência e maior importância entre as presas registradas. A composição da dieta foi relativamente semelhante à de outras espécies do gênero Crossodactylus. O volume das presas foi positivamente relacionado com o tamanho e o peso dos espécimes, sugerindo que os indivíduos podem se alimentar de qualquer presa que eles possam engolir. A dieta apresentou variação entre os sexos. Apesar das fêmeas serem maiores e mais pesadas do que os machos, elas consumiram mais presas menores e ingeriram mais categorias de presas. Sugere-se que C. timbuhy tenha hábito alimentar invertebrado-oportunista. É provável que $C$. timbuhy apresente uma combinação de estratégias "senta-e-espera" e "forrageador ativo" devido ao alto consumo de presas altamente móveis e de presas sedentárias. Palavras-chave: Amphibia; ecologia trófica; Mata Atlântica; preferência alimentar; predação. 


\section{Introduction}

The Atlantic Forest comprises one of the biodiversity hotspots in the world (Myers et al. 2000). Despite its importance for conservation, the remaining forest still faces habitat loss and fragmentation (Ribeiro et al. 2011). The priorities for conservation are sites with high number of species, endemism, and threatened species. It is noteworthy that several key sites for conservation have new species discovered annually (Rossa-Feres et al. 2017). For example, the municipality of Santa Teresa, in southeastern Brazil, harbors more than 100 species of frogs, some of them only recently described (e.g. Ferreira et al. 2019).

Anurans play an important role in ecosystem functionality because they can act as predator and prey (Caldart et al. 2011, Hocking \& Babbitt 2014). They are mainly opportunistic predators feeding mostly on small invertebrates (Solé \& Rödder 2009, Cicort- Lucaciu et al. 2011, Ferreira et al. 2012). Some species have a narrow diet or even specialization on certain prey categories. For example, species of Rhinella and Dendrobates are mostly specialist on ants, beetles or termites (Solé et al. 2002, Ferreira \& Teixeira 2012, Martínez et al. 2019). On the other hand, species of Eleutherodactylus and Ceratophrys have highly generalist diets, but with concentrated consumption on few prey categories (Duellman \& Lizana 1994, Olson \& Beard 2012). As prey, anurans contribute to the energy flow to higher trophic levels (Pough 1980). In addition to contributing to the knowledge of the natural history of species, the diet composition information is useful to understand intra and interspecific interactions in trophic webs, energy flow and ecosystem functioning.

The diet composition is closely related to feeding strategy (Toft 1980, Toft 1981, Huey \& Pianka 1981, Perry \& Pianka 1997). In general, sit-and-wait foragers are effective at capturing actively moving prey and have generalized feeding habits (Duellman \& Trueb 1994). Contrarily, active foragers are effective at capturing sedentary prey and have specialized feeding habits (Huey \& Pianka 1981, Toft 1981, Duellman $\&$ Trueb 1994). Some predators have more plasticity regarding feeding strategy by consuming both active and sedentary preys (Caldart et al. 2012). Also, most species can also adapt feeding strategy according to food availability (Huey \& Pianka 1981, Menin et al. 2005).

The genus Crossodactylus Duméril and Bibron, 1841 belongs to the family Hylodidae and is composed of 14 species occurring in Brazil, Argentina and Paraguay (Frost 2020). Some species of Crossodactylus have small range distribution. For example, Crossodactylus timbuhy Pimenta, Cruz and Caramaschi, 2014 has been recorded only from Santa Teresa and Cachoeiro de Itapemirim municipalities, in the central region of Brazilian Atlantic Forest (Pimenta et al. 2014, Frost 2020). Diet studies suggests that ants are the main prey item of the species on the genus Crossodactylus, as shown for C. gaudichaudii Duméril \& Bibron, 1841 (Almeida-Gomes et al. 2007), C. trachystomus (Reinhardt \& Lütken, 1862) (previously C. bokermanni; Wachlevski et al. 2008), C. schmidti Gallardo, 1961 (Caldart et al. 2012) and C. aeneus Müller, 1924 (Jordão-Nogueira et al. 2006).

Crossodactylus timbuhy was recently described and there is still no information regarding its natural history, including its diet composition and feeding strategy. Here we analyzed the diet of one population of C. timbuhy in its type locality. We specifically aimed to determine the diet composition, the most important food items, and the feeding strategy. We also evaluated the relation between prey ingestion and body measures due to its relation to feeding strategy.

\section{Material and Methods}

Fieldwork was carried out at Augusto Ruschi Biological Reserve (Reserva Biológica Augusto Ruschi; $19^{\circ} 45^{\prime}$ and 20 ${ }^{\circ} 00^{\prime}$ S, 40 $27^{\circ}$ and $40^{\circ} 38^{\prime} \mathrm{W}$ ), municipality of Santa Teresa, state of Espírito Santo, southeastern Brazil. This mountainous region is covered by montane and sub-montane vegetation (Rizzini 1979, Brasil 1983). Climate is classified as humid subtropical with temperate summer $(\mathrm{Cfb})$ according to Köppen's classification (Alvares et al. 2014).

Sampling was performed along the Cachoeira trail (19 $54^{\prime}$ to $19^{\circ} 55^{\prime}$ S, $\left.40^{\circ} 33^{\prime} \mathrm{W}\right)$. Pitfall traps were originally designed to insect sample and also captured the anurans donated to us by the orthopteran researchers (see Acknowledgments; sampling permit ICMBio 37717-1). In total, 150 pitfall traps (buckets of $15 \mathrm{~cm}$ diameter and $15 \mathrm{~cm}$ height) were used in June 2013. Five buckets were placed in a line every $30 \mathrm{~m}$ along a $900 \mathrm{~m}$ transect on the forest floor and $200 \mathrm{~m}$ from a stream. Traps remained open for 48 hours. Buckets were filled with $70 \%$ ethanol for material preservation.

Adult frog specimens were weighed with a precision scale ( \pm $0.01 \mathrm{~g}$ precision) and snout-vent length (SVL) was measured with calipers ( $\pm 0.1 \mathrm{~mm}$ precision). Upon removal of stomach content, sex of the specimens was also determined. Each prey item was identified at the lowest possible taxonomic level following Triplehorn \& Johnson (2011) and Rafael et al. (2012). We distinguished the order Hymenoptera between Formicidae and Non-Formicidae categories. The larvae of different insect taxa were inserted into the category Insect larvae. The specimens were deposited in the Zoological Collection of the Museu de Biologia Professor Mello Leitão from the Atlantic Forest National Institute (Instituto Nacional da Mata Atlântica - INMA), Espírito Santo state, Brazil (MBML 8606-8633, 8635-8658, 8661-8674).

We counted the number of food items contained in each stomach, for each category of prey, and calculated the number of prey items ingested $(\mathrm{N})$. The frequency of occurrence of each taxon relative to total of analyzed stomachs (F\%) was also calculated. Length (L) and width (W) of each prey item were measured with calipers ( $\pm 0.1 \mathrm{~mm}$ precision) to calculate prey volume using the formula: $\mathrm{V}=4 / 3 \pi * \mathrm{~L} / 2 *(\mathrm{~W} / 2)^{2}$ (Biavati et al. 2004). The percentage was also calculated for number and volume of prey. Index of relative importance of each taxon was based on: $I x=(\mathrm{N} \%+\mathrm{F} \%+\mathrm{V} \%) / 3$ (according the modification proposed by Santos-Pereira et al. 2015). All these indices were calculated for both sexes together and for males and females separately.

The feeding strategy was calculated using the prey-specific abundance method and represented graphically (Amundsen et al. 1996). The prey-specific abundance was calculated as $\mathrm{P}_{i}=\left(\sum \mathrm{S}_{i} / \sum \mathrm{St}_{i}\right) \times 100$, where $\mathrm{S}_{i}$ is the stomach content comprising the number of prey $i$ and $\mathrm{St}_{i}$ is the total number of prey items in those stomachs with prey $i$ (Amundsen et al. 1996). For graphical representation of the feeding strategy of C. timbuhy, the prey specific abundance $\left(\mathrm{P}_{i}\right)$ was plotted against the frequency of occurrence $(\mathrm{F} \%)$ of each prey category, and graph interpretation followed Amundsen et al. (1996).

Data normality was determined by D'Agostino test (Ayres et al. 2007). The two-sample t-test was used to compare SVL and weight between males and females. We used Linear Regressions to evaluate the relation between SVL and weight; and Spearman Rank Correlation to assess the relation between frog size (SVL and weight) and the variables related to ingestion of prey ( $\mathrm{N}$ and $\mathrm{V})$. 
Positive correlation between frog size and prey volume indicates frogs feed upon any prey that they can swallow (i.e. opportunistic feeder). Data were analyzed in Statistica (version 7.1) and R (R Core Team, 2014). The significance level was $P \leq 0.05$ (Zar 2010). The mean and standard deviation (SD) were provided.

\section{Results}

\section{Characterization of the frog sample}

We evaluated the stomach content of 66 specimens of C. timbuhy, 15 males and 51 females. The sex ratio was 1:3.4 (male:female). Male SVL was $20.32 \pm 1.63 \mathrm{~mm}$ and female SVL was $23.52 \pm 1.29 \mathrm{~mm}$. Male weight was $0.76 \pm 0.15 \mathrm{~g}$ and female weight was $1.25 \pm 0.20 \mathrm{~g}$. Females were larger $(\mathrm{t}=7.91 ; \mathrm{P}<0.001)$ and heavier $(\mathrm{t}=8.71 ; \mathrm{P}<0.001)$ than males. There was positive relation between $\mathrm{SVL}$ and weight considering both sexes together $\left(\mathrm{F}_{1,64}=98.104 ; \mathrm{P}<0.001 ; \mathrm{R}^{2}=0.599\right)$ and only females $\left(\mathrm{F}_{1,49}=26.616 ; \mathrm{P}<\right.$ $\left.0.001 ; \mathrm{R}^{2}=0.338\right)$, but not for males $\left(\mathrm{F}_{1,13}=2.478 ; \mathrm{P}=0.137 ; \mathrm{R}^{2}=0.096\right)$.

\section{Diet composition}

We identified 466 prey items from 20 categories, and all frogs had at least one prey item in their stomach content (Table 1). The mean number of prey items per stomach was $7.1 \pm 5.9$. The mean prey volume per stomach was $32.6 \pm 63.5 \mathrm{~mm}^{3}$. Formicidae, Coleoptera and Insect larvae had the highest numerical proportion of prey items (N\% $=31.5,15.9$ and 14.6, respectively). Formicidae and Coleoptera had the highest frequency of occurrence $(\mathrm{F} \%=63.6$ both $)$. Coleoptera had the highest volume of prey ingested $(\mathrm{V} \%=20.0)$. Formicidae was the most important prey item for $C$. timbuhy, followed by Coleoptera and Insecta larvae $(I x=35.6,33.2$ and 27.6; Table 1).

\section{Sexes differences on diet}

Analyzing each sex separately, the mean number of prey items per stomach was $8.3 \pm 8.0$ for males, and $6.7 \pm 5.2$ for females. The mean prey volume per stomach was $16.8 \pm 17.2 \mathrm{~mm}^{3}$ for males, and $37.3 \pm 71.2$ $\mathrm{mm}^{3}$ for females. Formicidae and Coleoptera had the highest numerical proportion of prey items for males ( $\mathrm{N} \%=37.9$ and 16.1, respectively);

Table 1. Prey items consumed by Crossodactylus timbuhy in the Augusto Ruschi Biological Reserve, Espírito Santo state, southeastern Brazil: number of prey items $(\mathrm{N})$, frequency of occurrence $(\mathrm{F} \%)$ in stomachs, volume of prey items $(\mathrm{V})$, and relative importance of each prey (Ix). For number and volume of prey the percentage is also shown (in parentheses).

\begin{tabular}{|c|c|c|c|c|c|c|c|c|c|c|c|c|}
\hline \multirow[t]{2}{*}{ Prey category } & \multicolumn{3}{|c|}{ Male $(\mathrm{N}=15)$} & \multirow[b]{2}{*}{$\mathbf{I x}$} & \multicolumn{3}{|c|}{ Female $(\mathrm{N}=51)$} & \multicolumn{5}{|c|}{ Population $(N=66)$} \\
\hline & $\mathbf{N}(\%)$ & F\% & $\mathrm{V}(\%)$ & & $\mathrm{N}(\%)$ & $\mathbf{F \%}$ & $\mathrm{V}(\%)$ & $\mathbf{I x}$ & $\mathrm{N}(\%)$ & F\% & $\mathrm{V}(\%)$ & $\mathbf{I x}$ \\
\hline \multicolumn{13}{|l|}{ Arachnida } \\
\hline Araneae & $15(12.1)$ & 66.7 & $15.8(6.2)$ & 28.3 & $27(7.9)$ & 39.2 & $78.0(5.4)$ & 17.5 & $42(9.0)$ & 45.6 & $93.8(5.6)$ & 20.0 \\
\hline Pseudoscorpionida & - & - & - & - & $1(0.3)$ & 2.0 & $0.6(0.0)$ & 0.8 & $1(0.2)$ & 1.5 & $0.6(0.0)$ & 0.6 \\
\hline Chilopoda & $1(0.8)$ & 6.7 & $3.9(1.5)$ & 3.0 & $1(0.3)$ & 2.0 & $0.3(0.0)$ & 0.8 & $2(0.4)$ & 3.0 & $4.2(0.2)$ & 1.2 \\
\hline Diplopoda & - & - & - & - & $1(0.3)$ & 2.0 & $2.2(0.2)$ & 0.8 & $1(0.2)$ & 1.5 & $2.2(0.1)$ & 0.6 \\
\hline \multicolumn{13}{|l|}{ Insecta } \\
\hline Blattodea & - & - & - & - & $1(0.3)$ & 2.0 & $1.3(0.1)$ & 0.8 & $1(0.2)$ & 1.5 & $1.3(0.1)$ & 0.6 \\
\hline Coleoptera & $20(16.1)$ & 66.7 & $46.4(18.3)$ & 33.7 & $54(15.8)$ & 62.7 & $290.9(20.3)$ & 32.9 & $74(15.9)$ & 63.6 & $337.3(20.0)$ & 33.2 \\
\hline \multicolumn{13}{|l|}{ Hymenoptera } \\
\hline Non-Formicidae & $12(9.7)$ & 53.3 & $22.1(8.7)$ & 23.9 & $36(10.5)$ & 43.1 & $144.8(10.1)$ & 21.3 & $48(10.3)$ & 45.5 & $166.9(9.9)$ & 21.9 \\
\hline Formicidae & $47(37.9)$ & 73.3 & $51.7(20.4)$ & 43.9 & $100(29.2)$ & 60.8 & $144.0(10.0)$ & 33.4 & $147(31.5)$ & 63.6 & $195.7(11.6)$ & 35.6 \\
\hline Isoptera & $2(1.6)$ & 13.3 & $0.3(0.1)$ & 5.0 & $2(0.6)$ & 2.0 & $12.1(0.8)$ & 1.1 & $4(0.9)$ & 4.5 & $12.7(0.7)$ & 2.0 \\
\hline Insect larvae & $13(10.5)$ & 53.3 & $20.2(8.0)$ & 23.9 & $55(16.1)$ & 51.0 & $261.5(18.2)$ & 28.4 & $68(14.6)$ & 51.5 & $281.6(16.7)$ & 27.6 \\
\hline Mantodea & - & - & - & - & $1(0.3)$ & 2.0 & $3.9(0.3)$ & 0.8 & $1(0.2)$ & 1.5 & $3.9(0.2)$ & 0.7 \\
\hline Orthoptera & $1(0.8)$ & 6.7 & $52.0(20.5)$ & 9.3 & $3(0.9)$ & 3.9 & $57.3(4.0)$ & 2.9 & $4(0.9)$ & 4.5 & $109.3(6.5)$ & 4.0 \\
\hline Trichoptera & - & - & - & - & $1(0.3)$ & 2.0 & $1.1(0.1)$ & 0.8 & $1(0.2)$ & 1.5 & $1.1(0.1)$ & 0.6 \\
\hline
\end{tabular}


Formicidae, Insect larvae and Coleoptera for females $(\mathrm{N} \%=29.2$, 16.1 and 15.8, respectively; Table 1). Formicidae, Araneae and Coleoptera had the highest frequency of occurrence for males ( $\mathrm{F} \%$ $=73.3,66.7$ and 66.7, respectively); Coleoptera and Formicidae for females $(\mathrm{F} \%=62.7$ and 60.8 , respectively). Orthoptera and Formicidae had the highest volume in males $(\mathrm{V} \%=20.5$ and 20.4 , respectively); Coleoptera, Insect Larvae and Diptera in females $(\mathrm{V} \%=20.3$, 18.2 and 13.0; Table 1). Formicidae and Coleoptera were the most important prey items for both males and females (male $I x=43.9$ and 33.7, respectively; female $I x=33.4$, and 32.9, respectively; Table 1).

Prey number was not related to frog SVL $(\mathrm{rs}=0.032 ; \mathrm{P}=0.798 ; 66$ pairs) or frog weight ( $\mathrm{rs}=0.000 ; \mathrm{P}=0.994 ; 66$ pairs) for all population, even when analyze females ( $\mathrm{rs}=0.047 ; \mathrm{P}=0.743$ and $\mathrm{rs}=0.049 ; \mathrm{P}$ $=0.728 ; 51$ pairs $)$ or males separately $(\mathrm{rs}=0.362 ; \mathrm{P}=0.184$ and $\mathrm{rs}=$ $0.407 ; \mathrm{P}=0.131 ; 15$ pairs). Prey volume was positively related to frog $\mathrm{SVL}(\mathrm{rs}=0.274 ; \mathrm{P}=0.026 ; 66$ pairs $)$ and frog weight $(\mathrm{rs}=0.323 ; \mathrm{P}=$ $0.008 ; 68$ pairs) for all population. For males, prey volume was related to weight ( $\mathrm{rs}=0.636 ; \mathrm{P}=0,011 ; 15$ pairs), but not to $\mathrm{SVL}$ ( $\mathrm{rs}=0.438 ; \mathrm{P}$ $=0.103 ; 15$ pairs). For females, prey volume was not related to SVL (rs $=0.150 ; \mathrm{P}=0.292 ; 51$ pairs $)$ or weight $(\mathrm{rs}=0.232 ; \mathrm{P}=0.100 ; 51$ pairs $)$.

\section{Feeding strategy}

There was no dominant prey type on the diet of C. timbuhy due to the absence of any prey type in the upper right corner of the graph (Fig. 1). Most prey types were rare in the diet due to their positioning in the lower left corner of the graph. No between-phenotype component to the niche width nor within-phenotype component to any food type were observed. Thus, there is no specialization to any food type by individuals, although there is a tendency for diet generalization within the population of C. timbuhy (Fig. 1). Crossodactylus timbuhy is likely an invertebrate-opportunistic feeder.

\section{Discussion}

\section{Diet composition and Feeding strategy}

Our results corroborate other studies showing Crossodactylus species feed mainly on Formicidae, Coleoptera and Insect larvae (JoãoNogueira et al. 2006, Almeida-Gomes et al. 2007, Wachlevski et al. 2008, Caldart et al. 2012). Although the primary prey taxa consumed by $C$. timbuhy was similar to other congeners, the secondary items differed across species. Despite this, our data corroborated Caldart et al. (2012) who stated that the diet composition is relatively similar across Crossodactylus species. The diet similarities may reflect similar prey availability at the forest leaf litter and margins of forest streams, as proposed for Hylodidae species (Wachlevski et al. 2008).

The wide spectrum of prey taxa consumed by C. timbuhy suggests that this species has an opportunistic feeding habit. It is noteworthy mentioning, however, the high consumption of Formicidae, and that only worker ants were in the stomach content of C. timbuhy. The consumption of high abundance of worker ants can be a consequence of opportunistic feeding habit and prey availability, associated with the poor nutritional value of this item, compared to queens for example, that have more protein and fat content (Pianka \& Parker 1975, Nielsen et al. 1985). Thus, may be advantageous to consume high number of workers to obtain the necessary energy supply, while avoiding the energy expenditure required to actively locate other types of prey with higher nutritional value (optimal foraging theory; Charnov 1976).

The consumption of both highly mobile insects (e.g. Formicidae) and sedentary ones (e.g. Insect larvae) indicated a combined use of both 'sit-and-wait' and 'active search' strategies (Huey \& Pianka 1981). Although we have not evaluated prey availability, other studies indicated that the diet of Crossodactylus species reflects the availability of prey in the environment (e.g. Wachlevski et al. 2008, Caldart et al. 2012).
A

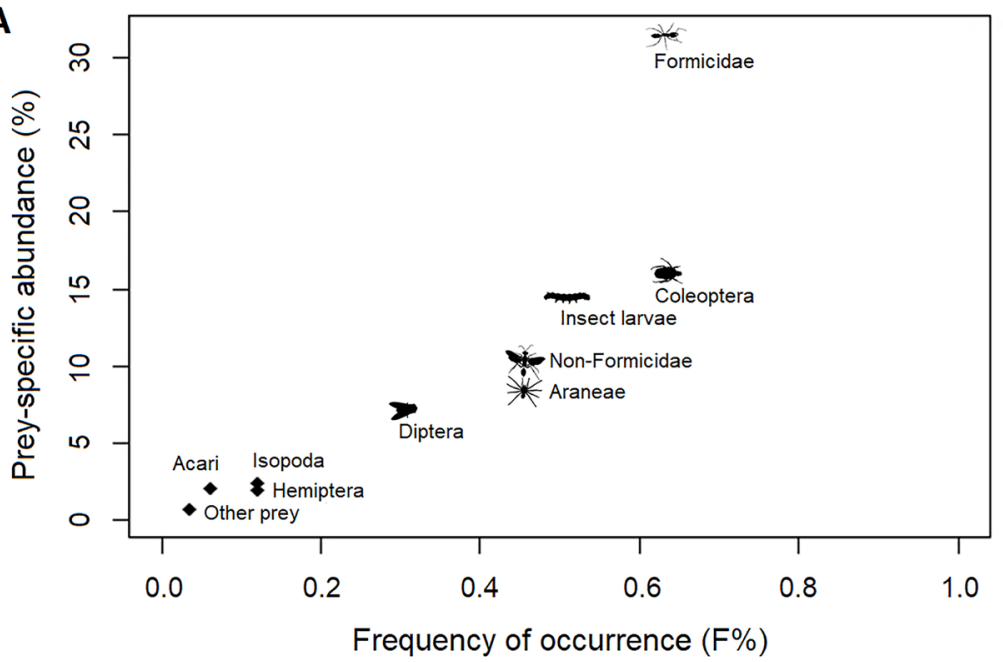

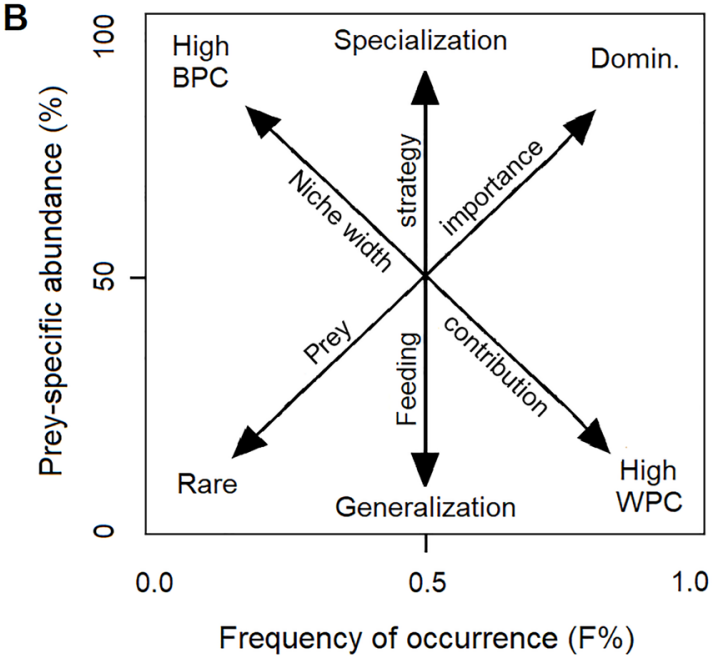

Figure 1. Feeding strategy of Crossodactylus timbuhy in the Augusto Ruschi Biological Reserve, Espírito Santo state, southeastern Brazil, according to preyspecific abundance (\%) and frequency of occurrence (F\%) of each prey category (A), and the diagram for feeding strategy interpretation considering the prey importance (rare to dominant), the niche width contribution (BPC = between-phenotype component; WPC = within-phenotype component) and the feeding strategy (B; based on Amundsen et al. 1996). For better visualization of Figure 1A, the y-axis was not shown in its total length. 
Because social arthropods comprise approximately $70 \%$ of animal biomass in tropical forest (Hölldobler \& Wilson 1990), it is not surprising that ants are important prey also for C. trachystomus (Wachlevski et al. 2008), C. gaudichaudii (Almeida-Gomes et al. 2007), C. schmidti (Caldart et al. 2012), and other anuran species such as Hylodes phyllodes Heyer \& Cocroft, 1986 (Hylodidae; AlmeidaGomes et al. 2008), Amazophrynella minuta (Melin, 1941) (previously Dendrophryniscus minutus; Bufonidae; Toft 1980), Rhinella crucifer (Wied-Neuwied, 1821) (Bufonidae; Ferreira \& Teixeira 2009) and Leptodactylus natalensis Lutz, 1930 (Leptodactylidae; Ferreira et al. 2007).

The SVL and weight of C. timbuhy were not related to the number of prey in the stomach, but was positively related to prey volume. Because Crossodactylus species have mouth width proportional to SVL and weight (Jordão-Nogueira et al. 2006), it is not surprising that larger and heavier individuals can feed upon more voluminous prey. Contrarily, SVL of C. schmidti and C. trachystomus have no relation to prey volume (respectively Caldart et al. 2012, Wachlevski et al. 2014). However, the size of the frog is generally a limiting factor in the selection of preys (Toft 1980, Borges et al. 2019).

\section{Sexes differences on diet and sample}

Diet showed some variation regarding number, frequency, and volume between males and females in the study area. Males were less opportunistic than females (13 prey categories), although males consume preys related to their weight, which can potentially allow the consumption of a wider range of prey. Despite females were larger and heavier than males, females had higher consumption of smaller prey and ingested a larger number of prey categories $(n=20)$. This higher tendency to opportunistic feeding by females may be related to the different energetic requirement between sexes (Duellman \& Trueb 1994). For example, the maturation of large sex cells requires that females reduce energy expenditure during foraging (e.g. maintaining the consumption of Formicidae) and target consumption on more energetic and small prey (e.g. insect larvae). However, it is possible that the differences observed may also be related, at least in part, to the analysis of a smaller number of male samples (15 males and 51 females).

The difference on habitat use may also be related to diet variation between sexes and sex ratio. The sex ratio of C. timbuhy is the most dissimilar across studied congener species. Interestingly, females had three times more individuals than males in our sample. We suggest that males of C. timbuhy may had been calling near the stream and thus had fallen less than females into pitfall traps in the forest (i.e. $>15 \mathrm{~m}$ from the stream's edge). The differences on sampling methods across studies on diet of Crossodactylus may play a role in such difference between males and females. Caldart et al. (2012) used pitfall traps about $1 \mathrm{~m}$ from the water's edge and capture 58 males and 36 females. Wachlevski et al. (2008) used active leaf-litter sampling in $2 \times 2 \mathrm{~m}$ quadrats at a stream bank and found 59 males and 39 females. According to Wachlevski et al. (2008), males of C. trachystomus are territorial and remain near stream margins. Contrarily to males, females may have preference for locations farther from stream's edge outside the reproductive period. Thus, the possible difference on habitat use between sexes may also influence the access to food resources due to the availability of prey in each environment.

\section{Conclusion}

Crossodactylus timbuhy is likely an invertebrate-opportunistic predator combining the use of both 'sit-and-wait' and 'active search' strategies. The species feeds upon similar prey to its congeners corroborating that diet composition is relatively similar across the genus. However, dietary studies of other species are still needed to determine whether prey preferences are conservative across the genus. The composition of the diet of C. timbuhy showed some variations between sexes. Females had higher tendency to opportunistic feeding, suggesting plasticity regarding diet and feeding strategy. We suggest that diet may be influenced by different energetic requirement between sexes and by the association between habitat preferences and prey availability, as well as sex ratio is influenced by habitat use $\mathrm{x}$ habitat sampled, but these patterns should be further investigated on future studies with Crossodactylus species.

\section{Acknowledgments}

We thank the project "Biota de Orthoptera do Brasil" for donation of frog specimens and Bromeligenous Project for field support. E.C. Campinhos thanks Universidade Vila Velha (UVV) and Fundação de Amparo à Pesquisa e Inovação do Espírito Santo (FAPES) for scholarships. R.B. Ferreira and M.M. Mageski thank Coordenação de Aperfeiçoamento de Pessoal de Nível Superior (CAPES - Finance Code 001). A.C. Srbek-Araujo is grateful to FAPES (607/2015 and 510/2016), which sponsored the research of the Laboratório de Ecologia e Conservação de Biodiversidade (LECBio).

\section{Author Contributions}

Ana Carolina Srbek-Araujo: Concept of the study, data analysis and interpretation, manuscript preparation.

Rodrigo Barbosa Ferreira: Concept of the study, data analysis and interpretation, manuscript preparation.

Elaine Costa Campinhos: Data analysis and interpretation, manuscript preparation.

Marcio Marques Mageski: Data analysis and interpretation, manuscript preparation.

\section{Conflicts of Interest}

The authors declare that they have no conflict of interest related to the publication of this manuscript.

\section{Ethics}

All the research meets the ethical guidelines, including adherence to the Brazilian legal requirements. The manuscript has been submitted solely to Biota Neotropica and is not published, in press, or submitted elsewhere.

\section{Data availability}

Our original data are fully described in the manuscript. 


\section{References}

ALMEIDA, A.P., GASPARINI, J.L. \& PELOSO, P.L.V. 2011. Frogs of the state of Espírito Santo, southeastern Brazil - The need for looking at the 'coldspots'. Check List 7:542-560.

ALMEIDA-GOMES, M., HATANO, F.H., SLUYS, M.V. \& ROCHA, C.F.D. 2007. Diet and microhabitat use by two Hylodinae species (Anura, Cycloramphidae) living sympatry and syntopy in a Brazilian Atlantic Rainforest area. Iheringia Série Zoologia 97:27-30.

ALVARES, C.A., STAPE, J.L., SENTELHAS, P.C., GONÇALVES, J.L.M. \& SPAROVEK, G. 2014. Köppen's climate classification map for Brazil. Meteorologische Zeitschrift 22:711-728.

AMUNDSEN, P.A., GABLER, H.M. \& STALDVIK, F.J. 1996. A new approach to graphical analysis of feeding strategy from stomach contents data-modification of the Costello (1990) method. Journal of Fish Biology 48:607-614.

AYRES, M., AYRES JR, M, AYRES, D.L. \& SANTOS, A.S. 2007. BioEstat: Aplicações Estatísticas nas áreas das Ciências Bio-Médicas. Version 5.3. Belém, Brasil, Sociedade Civil Mamirauá, MCT-CNPq.

BIAVATI, G.M., WIEDERHECKER, H.C. \& COLLI, G.R. 2004. Diet of Epipedobates flavopictus (Anura: Dendrobatidae) in a Neotropical Savanna. Journal of Herpetology 38:510-518.

BORGES, A.C.R., SANTOS, T.F., FRAZÃO, L., MARQUES-SOUZA, S. \& MENIN, M. 2019. Food habits of Rhinella proboscidea (Anura: Bufonidae) in terra firme forests of central Amazonia. Phyllomedusa 18:37-46.

BRASIL. 1983. Folhas SF. 23/24, Rio de Janeiro/Vitoria: geologia, geomorfologia, pedologia, vegetação, uso potencial da terra. Rio de Janeiro, Brazil, DNPM/Projeto RADAMBRASIL.

CALDART, V.M., IOP, S., BERTASO, T.R.N. \& CECHIN, S.Z. 2012. Feeding ecology of Crossodactylus schmidti (Anura: Hylodidae) in Southern Brazil. Zoological Studies 51:484-493.

CHARNOV, E.L. 1976. Optimal foraging: The marginal value theorem. Theoretical Population Biology 9:129-136.

CICORT-LUCACIU, A.S., CUPSA, D., ILIES, D., ILIES, A., BAIAS, S. $\&$ SAS, I. 2011. Feeding of two amphibian species (Bombina variegata and Pelophylax ridibundus) from artificial habitats from Pădurea Craiului Mountains (Romania). North-Western Journal of Zoology 7:297-303.

DUELLMAN, W.E. \& LIZANA, M. 1994. Biology of a sit-and-wait predator, the leptodactylid frog Ceratophrys cornuta. Herpetologica 50:51-64.

DUELLMAN, W. \& TRUEB, L. 1994. Biology of Amphibians. 2nd Edition. New York, USA, Johns Hopkins University Press.

FERREIRA, R.B., DANTAS, R.B. \& TEIXEIRA, R.L. 2007. Reproduction and ontogenetic diet shifts in Leptodactylus natalensis (Anura: Leptodactylidae) from southeastern Brazil. Boletim do Museu de Biologia Mello Leitão 22:45-55.

FERREIRA, R.B. \& TEIXEIRA, R.L. 2009. Feeding pattern and use of reproductive habitat of the Striped toad Rhinella crucifer (Anura: Bufonidae) from Southeastern Brazil. Acta Herpetologica 4:125-134.

FERREIRA, R.B., SCHINEIDER, J.A.P. \& TEIXEIRA, R.L. 2012. Diet, fecundity, and use of bromeliads by Phyllodytes luteolus (Anura: Hylidae) in southeastern Brazil. Journal of Herpetology 46:19-24.

FERREIRA, R.B., FAIVOVICH, J., BEARD, K.H. \& POMBAL-JÚNIOR, J.P. 2015. The first bromeligenous species of Dendropsophus (Anura: Hylidae) from Brazil's Atlantic Forest. PLoS ONE 10:e0142893.

FERREIRA, R.B., MÔNICO, A.T., SILVA, E.T., LIRIO, F.C.F., ZOCCA, C., MAGESKI, M.M., TONINI, J.F.R., BEARD, K.H., DUCA, C. \& SILVA-SOARES, T. 2019. Amphibians of Santa Teresa, Brazil: the hotspot further evaluated. Zookeys 857:139-162.

FROST, D.R. 2020. Amphibian species of the world: an online reference. Version 6.1. Electronic Database. Available at: https://amphibiansoftheworld.amnh. org/index.php. Accessed on 31 July 2020.

HOCKING, D.J. \& BABBITT, K.J. 2014. Amphibian contributions to ecosystem services. Herpetological Conservation and Biology 9:1-17.

HÖLLDOBLER, B. \& WILSON, E.O. 1990. The ants. Berlin, Springer.

HUEY, R.B. \& PIANKA, E.R. 1981. Ecological consequences of foraging mode. Ecology 62:991-999.
JORDÃO-NOGUEIRA, T., VRCIBRADIC, D., PONTES, J., VAN-SLUYS, M. \& ROCHA, C.F.D. 2006. Natural history traits of Crossodactylus aeneus (Anura: Leptodactylidae, Hylodinae) from Atlantic Rainforest area in Rio de Janeiro state, southeastern Brazil. South American Journal of Herpetology 1:37-41.

LOURENÇO-DE-MORAES, R., FERREIRA, R.B., FOUQUET, A. \& BASTOS, R.P. 2014. A new diminutive frog species of Adelophryne (Amphibia: Anura: Eleutherodactylidae) from the Atlantic Forest, southeastern Brazil. Zootaxa 3846:348-360.

MARTÍNEZ, M.M., ORTEGA, M.S.C., LOPERA, J.M.H. \& MORALES, J.A.R. 2019. Diet of the yellow striped poison frog, Dendrobates truncatus (Cope, 1861) (Anura: Dendrobatidae) from the Middle Magdalena river valley, Colombia. Herpetology Notes 12:1185-1191.

MENIN, M., ROSSA-FERES, D.C. \& GIARETTA, A.A. 2005. Resource use and coexistence of two syntopic hylid frogs (Anura, Hylidae). Revista Brasileira de Zoologia 22:61-72.

MYERS, N., MITTERMEIER, R.A., MITTERMEIER, C.G., FONSECA, G.A.B. \& KENT, J. 2000. Biodiversity hotspots for conservation priorities. Nature 403:853-858.

NIELSEN, M.G., SKYBERG, N. \& PEAKIN, G. 1985. Respiration in the sexuals of the ant Lasius flavus. Physiological Entomology 10:199-204.

OLSON, C.A. \& BEARD, K.H. 2012. Diet of the introduced greenhouse frog in Hawaii. Copeia 1:121-129.

PERRY, G. \& PIANKA, E.R. 1997. Animal foraging: past, present and future. Trends in Ecology \& Evolution 12:360-364.

PIANKA, E.R. \& PARKER, W.S. 1975. Ecology of horned lizards: A review with special reference to Phrynosoma platyrhinos. Copeia 1975:141-162.

PIMENTA, B.V.S., CRUZ, C.A.G. \& CARAMASCHI, U. 2014. Taxonomic review of the species complex of Crossodactylus dispar A. Lutz, 1925 (Anura, Hylodidae). Papéis Avulsos de Zoologia 45:1-33.

POLIS, G.A. \& MYERS, C.A. 1989. A survey of intraspecific predation among reptiles and amphibians. Journal of Herpetology 19:99-107.

POUGH, F.H. 1980. The advantages of ectothermy for tetrapods. The American Naturalist 115:912-112.

R CORE TEAM. 2014. R: A language and environment for statistical computing. Vienna, R Foundation for Statistical Computing.

RAFAel, J.A., Melo, G., CARVAlho, C., CASARI, C.A. \& CONSTANTINO, R. 2012. Insetos do Brasil: Diversidade e Taxonomia. Ribeirão Preto, Holos Editora.

RIBEIRO, M.C., MARTENSEN, A.C., METZGER, J.P., TABARELLI, M., SCARANO, F. \& FORTIN, M.J. 2011. The Brazilian Atlantic Forest: a shrinking biodiversity hotspot. In: Biodiversity Hotspots, p. 406-434. Zachos, F.E. and Habel, J.C., Eds., Berlin, Germany, Springer-Verlag.

RIZZINI, C.T. 1979. Tratado de Fitogeografia do Brasil: aspectos sociológicos e florísticos. São Paulo, Brazil, Hucitec/Edusp.

RÖDDER, D., TEIXEIRA, R.L., DANTAS, R.B., PERTEL, W. \& GUARNEIRE, G.J. 2007. Anuran hotspots: the municipality of Santa Teresa, Espírito Santo, southeastern Brazil. Salamandra 43:91-110.

ROSSA-FERES, D.C., GAREY, M.V., CARAMASCHI, U., NAPOLI, M.F., NOMURA, F., BISPO, A.A., BRASILEIRO, C.A., THOMÉ, M.T.C., SAWAYA, R.J., CONTE, C.E., CRUZ, C.A.G., NASCIMENTO, L.B., GASPARINI, J.L., ALMEIDA, A.P. \& HADDAD, C.F.B. 2017. Anfíbios da Mata Atlântica: lista de espécies, histórico dos estudos, biologia e conservação. In: Revisões em Zoologia: Mata Atlântica, p. 237-314. Monteiro Filho, E.L.A. and Conte, C.E., Eds, Curitiba, Editora UFPR.

SANTOS, E.M., ALMEIDA, A.V. \& VASCONCELOS, S.D. 2004. Feeding habits of six anuran (Amphibia: Anura) species in a rainforest fragment in Northeastern Brazil. Iheringia Série Zoologia 94:433-438.

SANTOS-PEREIRA, M., ALMEIDA-SANTOS, M., OLIVEIRA, F.B., SILVA, A.L. \& ROCHA, C.F.D. 2015. Living in a same microhabitat should means eating the same food? Diet and trophic niche of sympatric leaf-litter frogs Ischnocnema henselii and Adenomera marmorata in a forest of Southern Brazil. Brazilian Journal of Biology 75:13-18. 
SILVA, H.R., BRITTO-PEREIRA, M.C. \& CARAMASCHI, U. 1989. Frugivory and seed dispersal by Hyla truncata, a Neotropical tree-frog. Copeia 1989:781-783.

SOLÉ, M., DIAS, I.R., RODRIGUES, E.A.S., MARCIANO-JUNIOR, E., BRANCO, S.M.J., CAVALCANTE, K.P. \& RÖDDER, D. 2009. Diet of Leptodactylus ocellatus (Anura: Leptodactylidae) from a cacao plantation in southern Bahia, Brazil. Herpetology Notes 2:9-15.

SOLÉ, M. \& RÖDDER, D. 2009. Dietary assessments of adult amphibians. In: Amphibian ecology and conservation, p. 167-184. Dodd Jr, K., Ed., Oxford, UK, Oxford University Press.

TEIXEIRA, R.L. \& VRCIBRADIC, D. 2003. Diet of Leptodactylus ocellatus (Anura; Leptodactylidae) from coastal lagoons of southeastern Brazil. Cuadernos de Herpetologia 17:111-118.

TOFT, C.A. 1980. Feeding ecology of thirteen syntopic species of Anurans in a seasonal tropical environment. Oecologia 45:131-141.
TOFT, C.A. 1981. Feeding ecology of Panamanian litter anurans: patterns in diet and foraging mode. Journal of Herpetology 15:139-144.

TRIPLEHORN, C.A. \& JOHNSON, N.F. 2011. Estudo dos insetos. São Paulo, Cengage Learning.

WACHLEVSKI, M., SOUZA, P.H.C., KOPP, K. \& ETEROVICK, P.C. 2008. Microhabitat use and feeding habits of Crossodactylus bokermanni Caramaschi and Sazima, 1985 (Anura, Hylodidae) at a site in south-eastern Brazil. Journal of Natural History 42:1421-1434.

ZAR, J.H. 2010. Biostatistical analysis. 5th Edition. New Jersey, USA, Prentice Hall.

Received: $13 / 12 / 2019$

Revised: $17 / 08 / 2020$

Accepted: 25/08/2020

Published online: 25/09/2020 